\title{
Coleoptera Diversity and Soil Properties in Land Use Systems
}

\author{
Pâmela Niederauer Pompeo ${ }^{1}$ (1) 0000-0001-7209-2256 \\ Luís Carlos Iuñes de Oliveira Filho ${ }^{2}$ (1) 0000-0002-9010-481X \\ Osmar Klauberg Filho ${ }^{1}$ (1) 0000-0002-7733-9745 \\ Álvaro Luiz Mafra ${ }^{1}$ (i) 0000-0002-6751-4837 \\ Dilmar Baretta ${ }^{2}$ (D) 0000-0001-8219-1362
}

\begin{abstract}
This study aimed to evaluate the abundance and diversity of Coleoptera in five land use systems (LUS) and the soil properties that explain the distribution of these organisms. Uses involved native forest (NF), Eucalyptus plantation (EP), perennial pasture (PA), integrated crop-livestock (ICL) and no-tillage (NT) in western Santa Catarina, Brazil. Coleopterans were sampled by the methods of pitfall traps and soil monoliths during the winter and summer. Regardless of the LUS, 1,441 individuals were captured, with Staphylinidae being the most representative family ( 47\%). The use of NF showed higher abundances of coleopterans. The land use systems PA, NT, and ICL obtained high values of diversity of Coleoptera families, depending on the method and season of collection. The distribution of families was influenced by the sampling season, and some soil properties such as biopores, water content and phosphorus can explain the variation of abundance among the LUS.
\end{abstract}

Keywords: soil fauna, beetles, community ecology, biodiversity.

\section{INTRODUCTION AND OBJECTIVES}

The challenge of conciliating environmental conservation and increased agricultural production highlights the need to know better the biodiversity in ecosystems because they provide essential services for the maintenance of life on the planet. Thus, the soil has a primordial role in these ecosystem services (i.e. provisioning, regulating, supporting, and cultural) because it contributes to the regulation of the hydrological cycle, filtering of pollutants, carbon sequestration, nutrient cycling, besides sustaining a wide biological diversity, among other benefits (Bardgett \& Van Der Putten, 2014).

The conditions imposed by land use and management can change populations of edaphic organisms, with impacts on the support of environmental services, due to the direct and indirect effects on factors related to soil and plants (Baretta et al., 2014). In general, changes observed in the environments occur due to alterations in plant composition, climate changes and also by the intensification of land use, which may cause both positive and negative impacts on the communities living in the soil.

These communities include coleopterans (Coleoptera), which make up an important part of the edaphic invertebrate fauna and can be found in almost all environments, occupying most of the terrestrial niches (Erwin, 2004; Fountain-Jones et al., 2015). They greatly differ with respect to habits and utilize various food resources, being phytophagous, predators, fungivores, detritivores (Triplehorn \& Johnson, 2015). Some groups of invertebrates, including coleopterans, are particularly useful in environmental monitoring, since they are relatively easy to sample and identify, found during all year, present even in small and fragmented areas, and respond rapidly to changes caused in their living environment (Favero et al., 2011; Pompeo et al., 2016).

Recent studies have evaluated Coleoptera families or more specific groups of this order (e.g. subfamilies and species), relating them with changes in the environment, soil quality and habitat preferences. For example, indicators of impacts

\footnotetext{
${ }^{1}$ Universidade do Estado de Santa Catarina (UDESC Lages), Lages, SC, Brasil

${ }^{2}$ Universidade do Estado de Santa Catarina (UDESC Oeste), Chapecó, SC, Brasil
} 
on riparian areas (Stockan et al., 2014); species which negatively respond to low levels of soil $\mathrm{N}$ and $\mathrm{Mg}$ (Farias et al., 2015); families positively correlated with $\mathrm{Al}, \mathrm{Zn}, \mathrm{Cu}$, organic matter (OM), K, Ca, Mn, and sand contents in the soil (Portilho et al., 2011); groups associated with disorders caused by high-intensity management for wood removal in primary forests (França et al., 2016); and also fragmentation of the environment (Garcia et al., 2016). Therefore, studying Coleoptera families can be an excellent tool to understand the effects of anthropic disturbance and land use intensification in Santa Catarina State, Brazil, and to assess the consequences caused by these changes on the diversity of this group.

Based on the information presented above, the following hypotheses were tested: i) land uses and managements can interfere with the abundance, diversity and distribution of Coleoptera families; ii) environmental variables (soil chemical, physical, and microbiological attributes) can help to explain the composition of the Coleoptera community and diversity in the different environments. In this context, this study aimed to evaluate the diversity of Coleoptera families in land use systems and the environmental variables, in order to understand the distribution of these families in the western Santa Catarina State, Brazil.

\section{MATERIALS AND METHODS}

The study was conducted in the western Santa Catarina State, Brazil, in the municipalities of São Miguel do Oeste, Chapecó and Xanxerê. The climate of this region is characterized, according to the Köppen's climate classification, as humid mesothermal (Cfa), with mean annual temperature around $18-20{ }^{\circ} \mathrm{C}$, rainfalls distributed along the year, and hot summers (Alvares et al., 2013). The land use systems (LUS) evaluated in each municipality composed a gradient of land use intensity, namely: native forest (NF), Eucalyptus plantation (EP), perennial pasture (PA), integrated crop-livestock (ICL), and no-tillage (NT). The municipalities were selected based on their type of soil, history of management, and geographic characteristics, being considered as true replicates of LUS, totaling 15 study areas. The altitudes of the areas vary from 593 to $746 \mathrm{~m}$ above the sea level (Table 1) and the soils in these sites were classified as Red Latosols.

The studied fragments of NF refer to Atlantic Forest remains and were sites of transition between Mixed Ombrophilous Forest and Seasonal Semi-deciduous Forest, containing trails formed by the entry of people and production animals. EP areas were native grasslands and used as pasture prior to the planting of Eucalyptus spp; PAs were grassland areas with mixture or introduction of grasses, with predominance of Axonopus affinis. NT systems involve minimum soil disturbance, permanent cover, and crop rotation with soybean (Glycine max), corn (Zea mays), wheat (Triticum aestivum), black oat (Avena strigosa) and annual ryegrass (Lolium multiflorum). ICL systems had annual crops (soybean and corn) in the summer under direct seeding and cover crops (oat, wheat, and other grasses) in the winter, which were used as pasture for cattle. Herbicides, fungicides and insecticides were used in the ICL and NT systems. Additional information on the characteristics and history of the areas can be obtained in the study by Bartz et al. (2014).

Table 1. Characteristics of the native forest (NF), Eucalyptus plantation (EP), perennial pasture (PA), integrated crop-livestock (ICL), and no-tillage (NT) systems in the western Santa Catarina State, Brazil.

\begin{tabular}{|c|c|c|c|c|c|}
\hline Municipality & System & $\begin{array}{l}\text { Size } \\
\text { (ha) }\end{array}$ & $\begin{array}{c}\text { Age } \\
\text { (years) }\end{array}$ & $\begin{array}{l}\text { Geographic coordinates } \\
\text { UTM zone J22 }\end{array}$ & $\begin{array}{l}\text { Altitude } \\
\text { (m) }\end{array}$ \\
\hline \multirow[t]{5}{*}{ Xanxerê } & NF & 1 & - & 355588.12987031160 .621 & 714 \\
\hline & EP & 6 & 4 & 354841.10687036628 .879 & 709 \\
\hline & PA & 4.2 & 12 & 353941.0463355588 .1298 & 723 \\
\hline & ICL & 1.9 & 8 & 7031160.621354841 .1068 & 714 \\
\hline & NT & 6.2 & 18 & 7036628.8797030597 .288 & 746 \\
\hline \multirow[t]{5}{*}{ São Miguel do Oeste } & NF & 10.8 & $>50$ & 247891.07427040008 .463 & 648 \\
\hline & EP & 2.6 & 7 & 247846.98377040639 .510 & 659 \\
\hline & PA & 1.9 & 50 & 247970.7384247891 .0742 & 660 \\
\hline & ICL & 1.8 & 18 & 7040008.463247846 .9837 & 641 \\
\hline & NT & 3.2 & 4 & 7040639.5107039329 .886 & 642 \\
\hline \multirow[t]{5}{*}{ Chapecó } & NF & 7.6 & $>50$ & 331686.97987008603 .136 & 623 \\
\hline & EP & 3.5 & 15 & 332063.29337009274 .894 & 653 \\
\hline & PA & 5.4 & 50 & 336900.3742331686 .9798 & 642 \\
\hline & ICL & 5.1 & 10 & 7008603.136332063 .2933 & 593 \\
\hline & NT & 2.2 & 10 & 7009274.8947010937 .325 & 679 \\
\hline
\end{tabular}


Sampling was carried out in the winter (August 2011) and in the summer (December 2011), systematically, in a sampling grid of $3 \times 3$ points, spaced by $30 \mathrm{~m}$ with border of $20 \mathrm{~m}$, resulting in 270 points (three municipalities, five LUS, nine points in each, in two seasons).

Coleopterans were captured by two sampling methods, one from Tropical Soil Biology and Fertility (TSBF) (Anderson \& Ingram, 1993), which consists in the collection of soil monoliths with $25 \times 25 \mathrm{~cm}$ of side and $20 \mathrm{~cm}$ of depth, including the surface litter, using an iron sampler, followed by manual sorting. The second method was pitfall traps, which comprised cylindrical containers with $200 \mathrm{~mL}$ of detergent solution at $0.5 \%(\mathrm{v} / \mathrm{v})$, buried in the soil with their open end flush with the surface, maintained for three days in the field (Baretta et al., 2014).

Samples collected by traps and soil monoliths were cleaned, sorted, and the coleopterans were separated into morphospecies and identified up to family level using identification keys and/or characterizations found in the literature (Casari \& Ide, 2012; Lima, 1952, 1953, 1955; Triplehorn \& Johnson, 2015) and the nomenclature presented in the Taxonomic Catalog of the Brazilian Fauna (Monné \& Costa, 2018). The material was deposited in absolute alcohol at the Soil Ecology Laboratory of Centro de Ciências Agroveterinárias, in Universidade do Estado de Santa Catarina (CAV/UDESC) in Lages, SC.
For soil chemical and microbiological analyses, 15 subsamples were collected around each point of the sampling grid in the 0-20 cm layer, to form a representative composite sample. Chemical evaluations followed the methodology of Tedesco et al. (1995), microbial activity was evaluated by determining microbial basal respiration (MR) (Alef \& Nannipieri, 1995), and total organic carbon (TOC) was determined by dry combustion in a Vario EL Cube elemental analyzer of CHNS (Table 2).

The soil for physical analyses (Table 2) was sampled with 5-cm-high, 5-cm-diameter steel cylinders and the following attributes were analyzed: total porosity (TP) and biopores (Bio), according to the manual of EMBRAPA (1997). Resistance to penetration (RP) was evaluated using a Marconi benchtop penetrometer. Soil samples with clods were separated for evaluation of mean weight-diameter of aggregates (MWD), by wet sieving (Kemper \& Chepil, 1965). Particle size was determined by the pipette method (Gee \& Bauder, 1986). To determine volumetric soil water content, the samples were dried at $105^{\circ} \mathrm{C}$ for 24 hours (EMBRAPA, 1997).

The list of identified Coleoptera families was used to construct a Venn diagram to better visualize the inventory, considering the collection methods and sampling seasons, using the VennDiagram package in the statistical program R (R Core Team, 2017).

Table 2. Mean values \pm standard deviation of soil attributes in the $0-20 \mathrm{~cm}$ layer in native forest (NF), Eucalyptus plantation (EP), perennial pasture (PA), integrated crop-livestock (ICL), and no-tillage (NT) systems in the western Santa Catarina State, Brazil.

\begin{tabular}{|c|c|c|c|c|c|}
\hline \multirow{2}{*}{ Soil attribute } & NF & EP & PA & ICL & NT \\
\hline & \multicolumn{5}{|c|}{ Winter } \\
\hline TOC $\left(\mathrm{g} \mathrm{kg}^{-1}\right)$ & $49.64 \pm 10.14$ & $31.07 \pm 3.34$ & $41.37 \pm 5.90$ & $31.73 \pm 3.65$ & $31.24 \pm 2.61$ \\
\hline $\mathrm{C} / \mathrm{N}$ & $12.3 \pm 0.9$ & $13.0 \pm 1.0$ & $13.4 \pm 0.8$ & $12.9 \pm 0.9$ & $12.7 \pm 1.1$ \\
\hline \multirow[t]{2}{*}{$\mathrm{Sw}(\%)(\mathrm{v} / \mathrm{v})$} & $54 \pm 10$ & $34 \pm 2$ & $44 \pm 8$ & $32 \pm 2$ & $32 \pm 2$ \\
\hline & \multicolumn{5}{|c|}{ Summer } \\
\hline TOC $\left(\mathrm{g} \mathrm{kg}^{-1}\right)$ & $47.99 \pm 8.09$ & $31.95 \pm 2.00$ & $44.11 \pm 6.76$ & $31.42 \pm 5.15$ & $30.98 \pm 4.19$ \\
\hline $\operatorname{MR}\left(\mu g^{-1} h^{-1}\right)$ & $85 \pm 28$ & $53 \pm 17$ & $102 \pm 22$ & $56 \pm 19$ & $60 \pm 20$ \\
\hline $\mathrm{C} / \mathrm{N}$ & $13.3 \pm 1.6$ & $14.6 \pm 2.1$ & $14.8 \pm 1.7$ & $14.6 \pm 0.7$ & $14.3 \pm 0.6$ \\
\hline pH SMP & $4.8 \pm 0.4$ & $5.2 \pm 0.2$ & $5.6 \pm 0.3$ & $5.8 \pm 0.2$ & $6.1 \pm 0.3$ \\
\hline Sw (\%) (v/v) & $40 \pm 9$ & $27 \pm 3$ & $30 \pm 5$ & $26 \pm 6$ & $25 \pm 5$ \\
\hline $\mathrm{K}\left(\mathrm{mg} \mathrm{dm}^{-3}\right)^{*}$ & $82.4 \pm 29.5$ & $105.6 \pm 62.5$ & $145.0 \pm 93.6$ & $178.1 \pm 102.3$ & $261.8 \pm 129.2$ \\
\hline $\mathrm{P}\left(\mathrm{mg} \mathrm{dm}^{-3}\right)^{*}$ & $5.2 \pm 1.4$ & $5.1 \pm 1.5$ & $4.7 \pm 1.8$ & $11.9 \pm 5.4$ & $14.9 \pm 4.9$ \\
\hline $\operatorname{Mg}\left(\mathrm{cmol}_{\mathrm{c}} \mathrm{dm}^{-3}\right)^{*}$ & $0.7 \pm 0.5$ & $1.2 \pm 0.4$ & $1.8 \pm 0.7$ & $2.3 \pm 0.6$ & $2.8 \pm 0.9$ \\
\hline $\mathrm{H}+\mathrm{Al}\left(\mathrm{cmol}_{\mathrm{c}} \mathrm{dm}^{-3}\right)^{*}$ & $19.6 \pm 8.4$ & $10.6 \pm 3.1$ & $7.4 \pm 3.1$ & $5.7 \pm 1.5$ & $4.2 \pm 1.4$ \\
\hline $\mathrm{Ca} / \mathrm{Mg}^{*}$ & $2.7 \pm 0.8$ & $2.5 \pm 0.8$ & $2.0 \pm 0.5$ & $2.3 \pm 0.2$ & $2.7 \pm 0.6$ \\
\hline $\mathrm{TP}\left(\mathrm{m}^{3} \mathrm{~m}^{-3}\right)^{*}$ & $0.64 \pm 0.04$ & $0.62 \pm 0.06$ & $0.60 \pm 0.03$ & $0.57 \pm 0.04$ & $0.59 \pm 0.03$ \\
\hline Bio $\left(\mathrm{m}^{3} \mathrm{~m}^{-3}\right)^{*}$ & $0.11 \pm 0.05$ & $0.06 \pm 0.03$ & $0.03 \pm 0.02$ & $0.07 \pm 0.06$ & $0.05 \pm 0.02$ \\
\hline Sand $\left(\text { dag } \mathrm{kg}^{-1}\right)^{\star}$ & $29.8 \pm 8.8$ & $29.5 \pm 6.2$ & $27.1 \pm 8.4$ & $27.3 \pm 8.6$ & $32.6 \pm 6.2$ \\
\hline $\operatorname{MWD}(\mathrm{mm})^{\star}$ & $5.24 \pm 0.64$ & $5.05 \pm 0.84$ & $5.69 \pm 0.40$ & $5.61 \pm 0.39$ & $5.39 \pm 0.64$ \\
\hline $\mathrm{RP}(\mathrm{MPa})^{\star}$ & $0.63 \pm 0.35$ & $1.55 \pm 1.17$ & $2.06 \pm 0.42$ & $1.48 \pm 0.34$ & $1.40 \pm 0.36$ \\
\hline
\end{tabular}

Means of replicates $(n=27) .{ }^{\star}$ Variable with the lowest alteration between seasons and determined only once. TOC: total organic carbon; $\mathrm{C} / \mathrm{N}$ : carbon/nitrogen ratio; P: phosphorus; K: potassium; $\mathrm{H}+\mathrm{Al}$ : potential acidity; $\mathrm{Ca} / \mathrm{Mg}$ : calcium/magnesium ratio; Sw: soil water content; Bio: biopores; MWD: mean weight-diameter of aggregates; MR: soil microbial respiration; $\mathrm{pH}$ SMP: hydrogen potential in SMP solution; Mg: magnesium; TP: total porosity; RP: resistance to penetration 
Evaluations were carried out for each land use system, using values of the nine points, considering the municipalities as true replicates $(n=3 \times 9=27)$, and each season was separately analyzed. The data obtained using both Coleoptera sampling methods (traps and soil monoliths) were also analyzed separately, i.e., the results were presented for each LUS, season, and type of collection. Differences in the abundance of coleopterans between the LUS were verified by the Kruskal-Wallis test ( $\alpha=5 \%$ ), using the program Statistica 7.0. Pielou (J), Shannon-Wiener diversity $\left(\mathrm{H}^{\prime}\right)$ indices were calculated using the Vegan package of the statistical program R (R Core Team, 2017).

Abundance data were subjected to multivariate statistical analysis. Data were initially subjected to a Detrended Correspondence Analysis (DCA) to check the gradient length and, due to the linear response $(<3)$, we decided to conduct Principal Component Analysis (PCA) for each studied season (winter and summer). Redundancy Analysis (RDA) was carried out to identify and remove collinear environmental variables (soil chemical, physical, and microbiological attributes), and to select a significant minimum set $(p \leq 0.05)$, based on permutations by the Monte-Carlo test. Only the environmental variables selected in the RDA were later used in the PCA as passive explanatory for the changes observed in the abundances of Coleoptera families (response variables) in the LUS. All multivariate statistical analyses were conducted using the statistical program CANOCO version 4.5 (Ter Braak \& Smilauer, 2002).

\section{RESULTS AND DISCUSSION}

\subsection{Abundance, richness and diversity of Coleoptera families}

A total of 1,441 coleopterans were captured, considering both sampling methods. The abundance of coleopterans differed between the LUS, considering monoliths and traps separately, as well as winter and summer (Figure 1). For traps in the winter, the highest abundance values were observed in ICL, PA, NF, NT, and EP, respectively, among which EP differed from ICL. In the summer, the abundance of coleopterans was higher in NF than in the other LUS. For the sampling by soil monoliths in the winter, the highest values were found in NF, followed by EP, PA, ICL, and NT, and in NT the abundance was lower and different from that of NF. Considering this methodology in summer, the highest values of abundance were found in PA, NF, NT, ICL, and EP. Among these systems, EP was significantly inferior to PA, NF, and NT, while ICL was similar to the others.
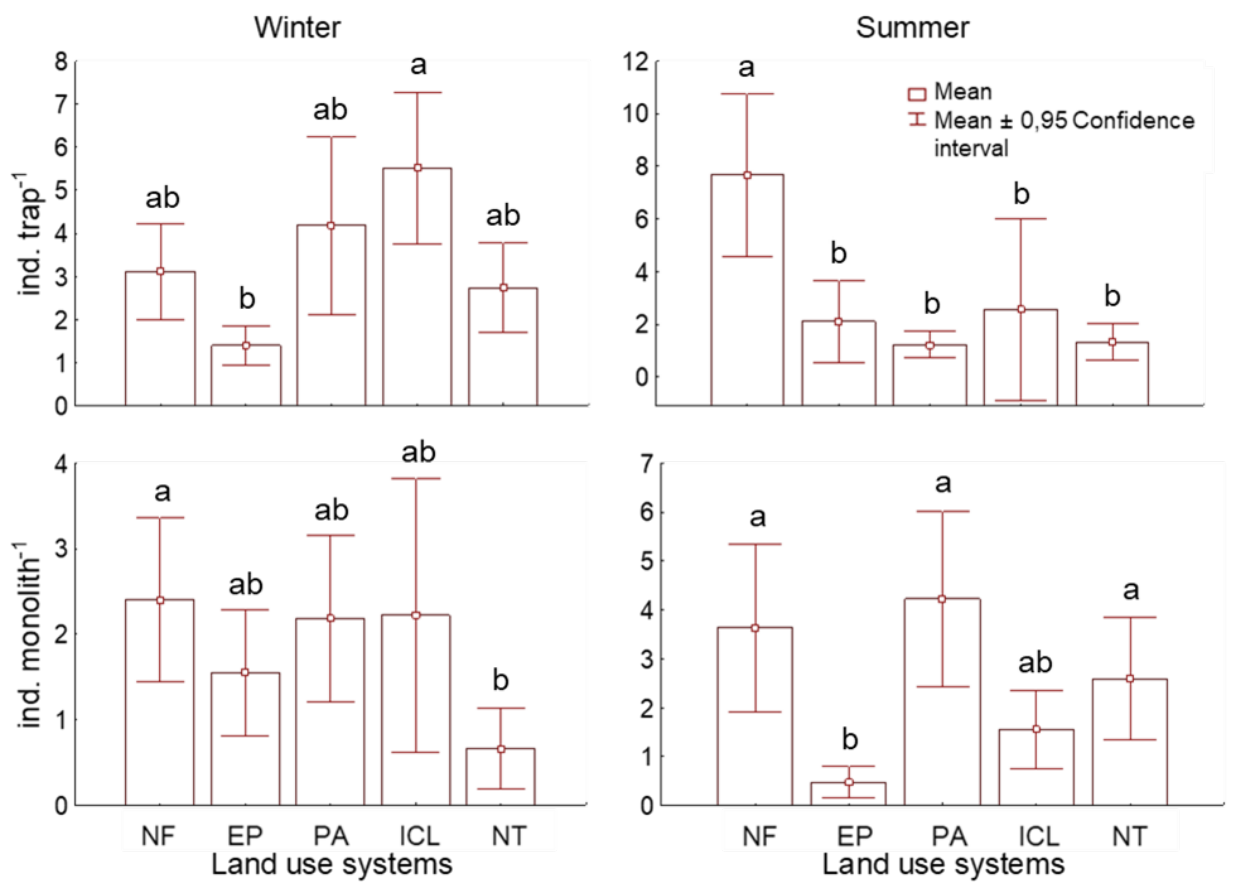

Figure 1. Average abundance of Coleoptera in native forest (NF), Eucalyptus plantation (EP), perennial pasture (PA), integrated croplivestock (ICL) and no-tillage (NT) systems in western Santa Catarina State, Brazil. Bars represented by mean values followed by the same letter are similar according to the Kruskal-Wallis test $(p<0.05 ; \mathrm{n}=27)$. 
It is known that areas under native vegetation such as NF and PA, in general, have higher floristic diversity compared to cultivation systems. Besides the diversity, the supply of organic residues, mainly in NF, in quantity and quality, can increase soil OM and favor the establishment of invertebrates in this environment (Rosa et al., 2015). These organisms benefit from the better conditions of food and habitat in these sites, and this can be interpreted by observing the results of Coleoptera abundance in the winter and summer seasons (Figure 1).

The lowest abundance observed in EP for the soil monolith method in the summer (Figure 1), although this system had lower land use intensification during crop development, is possibly associated with the plant diversity present in this system, which generates uniform litter (Primieri et al., 2017) that is less attractive to the edaphic fauna.

Coleopterans were distributed in 24 families (Figure 2), 12 of which occurred in both collection methods and sampling seasons. Four families (Ptiliidae, Leiodidae, Throscidae and Passalidae) were exclusively collected in the traps and three families (Ptilodactylidae, Cerambycidae, Erotylidae) were only collected in the monoliths (Figure 2).

The most abundant families observed in this study were Staphylinidae (680 individuals), Tenebrionidae (134), Carabidae (127), Scarabaeidae (115) and Nitidulidae (104) (Table 3). These results corroborate those reported by other authors who observed Staphylinidae, Scarabaeidae and/or Carabidae among the most representative groups in their studies, using pitfall traps and/or soil monoliths in different land uses and regions of the country (Favero et al., 2011; Garlet et al., 2015; Pompeo et al., 2016; Portilho et al., 2011).
The highest values of H' diversity and J evenness of Coleoptera families, sampled by traps in the winter, were observed in PA, followed by ICL, NT, NF, and EP (Table 3). In the summer, the highest values of these indices were found in NT, followed by EP, PA, NF, and ICL. This same pattern was also observed by Pompeo et al. (2016) for the H' and J indices, in the Santa Catarina highlands for the same LUS. For the Coleoptera families sampled by soil monoliths, the highest values of $\mathrm{H}^{\prime}$ and $\mathrm{J}$ in the winter were obtained in NT, followed by ICL, EP, $\mathrm{PA}$, and NF, whereas in the summer the highest values were found in ICL, followed by NT, PA, EP, and NF.

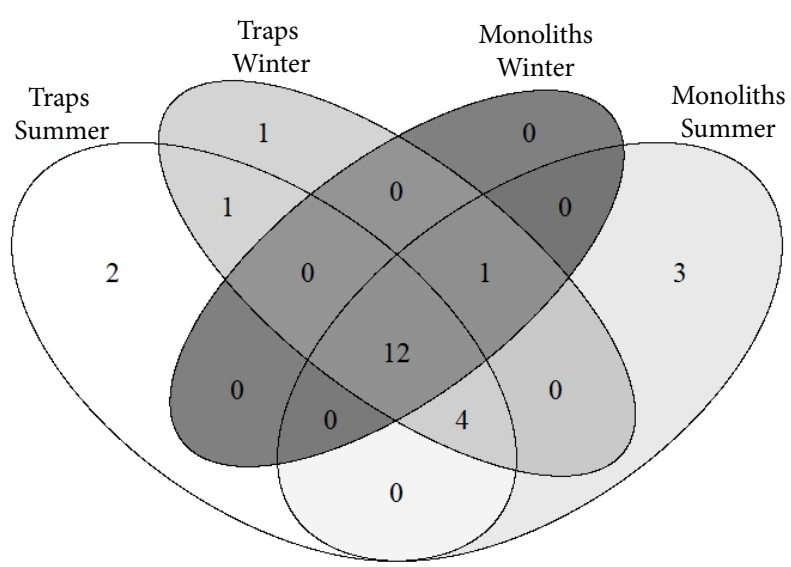

Figure 2. Venn diagram of the Coleoptera families considering two collection methods and sampling seasons, regardless of land use in the western Santa Catarina State, Brazil.

Table 3. Number of sampled individuals per Coleoptera family, richness and Shannon-Wiener diversity (H') and Pielou evenness (J) indices in native forest (NF), Eucalyptus plantation (EP), perennial pasture (PA), integrated crop-livestock (ICL), and no-tillage (NT) systems, in the winter (W) and summer (S) in the western Santa Catarina State, Brazil.

\begin{tabular}{|c|c|c|c|c|c|c|c|c|c|c|c|c|c|c|c|c|c|c|c|c|}
\hline \multirow{3}{*}{ Family } & \multicolumn{20}{|c|}{ Land use systems } \\
\hline & NF & EP & PA & ICL & NT & NF & EP & PA & ICL & NT & NF & EP & PA & ICL & NT & NF & EP & PA & ICL & NT \\
\hline & \multicolumn{5}{|c|}{ Trap (W) } & \multicolumn{5}{|c|}{ Trap (S) } & \multicolumn{5}{|c|}{ Monolith (W) } & \multicolumn{5}{|c|}{ Monolith (S) } \\
\hline Anthicidae & 0 & 0 & 2 & 0 & 2 & 0 & 0 & 3 & 4 & 11 & 0 & 0 & 1 & 0 & 0 & 0 & 0 & 1 & 2 & 12 \\
\hline Carabidae & 7 & 10 & 2 & 16 & 3 & 7 & 15 & 5 & 1 & 1 & 3 & 13 & 2 & 8 & 2 & 6 & 1 & 2 & 4 & 19 \\
\hline Cerambycidae $^{*}$ & 0 & 0 & 0 & 0 & 0 & 0 & 0 & 0 & 0 & 0 & 0 & 0 & 0 & 0 & 0 & 0 & 0 & 1 & 0 & 0 \\
\hline Chrysomelidae & 2 & 3 & 6 & 3 & 1 & 4 & 1 & 15 & 1 & 1 & 0 & 0 & 7 & 1 & 1 & 0 & 1 & 11 & 1 & 1 \\
\hline Corylophidae & 0 & 0 & 0 & 0 & 1 & 0 & 1 & 0 & 0 & 0 & 0 & 0 & 0 & 0 & 0 & 0 & 0 & 2 & 0 & 0 \\
\hline Curculionidae & 2 & 0 & 0 & 2 & 0 & 6 & 2 & 0 & 0 & 0 & 0 & 0 & 0 & 0 & 0 & 1 & 0 & 1 & 0 & 0 \\
\hline Dryopidae & 1 & 0 & 0 & 0 & 0 & 1 & 1 & 0 & 0 & 0 & 0 & 0 & 1 & 0 & 0 & 1 & 0 & 0 & 0 & 0 \\
\hline Elateridae & 0 & 0 & 3 & 3 & 0 & 1 & 1 & 0 & 0 & 0 & 0 & 0 & 1 & 1 & 0 & 4 & 1 & 11 & 0 & 0 \\
\hline Erotylidae & 0 & 0 & 0 & 0 & 0 & 0 & 0 & 0 & 0 & 0 & 0 & 0 & 0 & 0 & 0 & 0 & 0 & 0 & 1 & 0 \\
\hline Histeridae & 0 & 0 & 11 & 0 & 1 & 1 & 0 & 0 & 0 & 0 & 0 & 0 & 0 & 0 & 0 & 1 & 0 & 0 & 0 & 0 \\
\hline Latridiidae & 0 & 0 & 3 & 0 & 0 & 0 & 1 & 0 & 1 & 3 & 1 & 1 & 0 & 0 & 0 & 0 & 0 & 0 & 0 & 1 \\
\hline
\end{tabular}


Table 3. Continued...

\begin{tabular}{|c|c|c|c|c|c|c|c|c|c|c|c|c|c|c|c|c|c|c|c|c|}
\hline \multirow{3}{*}{ Family } & \multicolumn{20}{|c|}{ Land use systems } \\
\hline & NF & EP & PA & ICL & NT & NF & EP & PA & ICL & NT & NF & EP & PA & ICL & NT & NF & EP & PA & ICL & NT \\
\hline & \multicolumn{5}{|c|}{ Trap (W) } & \multicolumn{5}{|c|}{ Trap (S) } & \multicolumn{5}{|c|}{ Monolith (W) } & \multicolumn{5}{|c|}{ Monolith (S) } \\
\hline Leiodidae & 0 & 0 & 2 & 0 & 1 & 0 & 0 & 0 & 0 & 0 & 0 & 0 & 0 & 0 & 0 & 0 & 0 & 0 & 0 & 0 \\
\hline Nitidulidae & 13 & 6 & 12 & 37 & 18 & 8 & 8 & 0 & 0 & 1 & 0 & 0 & 0 & 0 & 0 & 1 & 0 & 0 & 0 & 0 \\
\hline NI & 0 & 0 & 0 & 0 & 0 & 0 & 0 & 0 & 0 & 0 & 0 & 0 & 0 & 1 & 0 & 0 & 0 & 0 & 0 & 0 \\
\hline Passalidae $^{*}$ & 0 & 0 & 0 & 0 & 0 & 1 & 0 & 0 & 0 & 0 & 0 & 0 & 0 & 0 & 0 & 0 & 0 & 0 & 0 & 0 \\
\hline Phalacridae & 0 & 0 & 1 & 0 & 0 & 0 & 0 & 0 & 0 & 1 & 1 & 0 & 0 & 0 & 0 & 0 & 0 & 0 & 2 & 0 \\
\hline Ptiliidae & 4 & 0 & 5 & 30 & 1 & 13 & 0 & 0 & 0 & 0 & 0 & 0 & 0 & 0 & 0 & 0 & 0 & 0 & 0 & 0 \\
\hline Ptilodactylidae ${ }^{*}$ & 0 & 0 & 0 & 0 & 0 & 0 & 0 & 0 & 0 & 0 & 0 & 0 & 0 & 0 & 0 & 0 & 1 & 0 & 0 & 0 \\
\hline Salpingidae & 0 & 0 & 3 & 6 & 0 & 0 & 0 & 0 & 0 & 0 & 0 & 0 & 0 & 0 & 1 & 0 & 0 & 0 & 1 & 1 \\
\hline Scarabaeidae & 19 & 8 & 1 & 1 & 0 & 38 & 7 & 1 & 6 & 6 & 8 & 2 & 0 & 0 & 1 & 10 & 0 & 7 & 0 & 0 \\
\hline Scydmaenidae & 0 & 0 & 1 & 0 & 3 & 1 & 2 & 0 & 0 & 2 & 1 & 0 & 0 & 0 & 0 & 1 & 0 & 2 & 0 & 0 \\
\hline Silvanidae & 0 & 0 & 0 & 1 & 1 & 0 & 0 & 0 & 0 & 3 & 0 & 0 & 0 & 1 & 3 & 0 & 0 & 0 & 1 & 3 \\
\hline Staphylinidae & 34 & 7 & 52 & 37 & 32 & 126 & 17 & 9 & 49 & 4 & 48 & 19 & 42 & 25 & 2 & 63 & 4 & 64 & 18 & 28 \\
\hline Tenebrionidae & 2 & 4 & 9 & 13 & 10 & 0 & 1 & 0 & 2 & 3 & 3 & 7 & 5 & 23 & 8 & 10 & 5 & 12 & 12 & 5 \\
\hline Throscidae & 0 & 0 & 0 & 0 & 0 & 0 & 0 & 0 & 5 & 0 & 0 & 0 & 0 & 0 & 0 & 0 & 0 & 0 & 0 & 0 \\
\hline Richness & 9 & 6 & 15 & 11 & 12 & 12 & 12 & 5 & 8 & 11 & 7 & 5 & 7 & 7 & 7 & 10 & 6 & 11 & 9 & 8 \\
\hline $\mathrm{H}^{\prime}$ & 1.7 & 1.7 & 2.0 & 1.9 & 1.7 & 1.3 & 1.9 & 1.3 & 1.1 & 2.1 & 1.0 & 1.3 & 1.0 & 1.3 & 1.6 & 1.3 & 1.5 & 1.5 & 1.6 & 1.5 \\
\hline $\mathrm{J}$ & 0.5 & 0.5 & 0.6 & 0.6 & 0.5 & 0.4 & 0.6 & 0.4 & 0.3 & 0.7 & 0.3 & 0.4 & 0.3 & 0.4 & 0.5 & 0.4 & 0.5 & 0.5 & 0.5 & 0.5 \\
\hline
\end{tabular}

${ }^{\star}$ Rare families with only one individual (singleton); NI: individual not identified.

High diversity in NT and ICL systems demonstrates the capacity of these land uses to maintain the community of Coleoptera families in equilibrium (Table 3). Maintenance of crop residues on the soil and crop rotation possibly contributed to these results. On the other hand, the anthropization of forest fragments, observed by the entry of people and domestic animals, as well as by the proximity with agricultural areas, may have been unfavorable to some groups of coleopterans, limiting the values of diversity in NF, which, despite being similar to those of the other LUS, were not the highest ones as expected.

\subsection{Principal Component Analysis (PCA) with explanatory environmental variables for the Coleoptera community}

PCA for coleopterans sampled by traps, in both seasons (Figure 3), demonstrated distinction between the land use systems, through the relation between the principal component 1 (PC1) and principal component 2 (PC2). Along with the results from Table 3 , this confirms the hypothesis that land use and management can interfere with the diversity and distribution of Coleoptera families.
For families sampled by traps in the winter (Figure 3a), the $\mathrm{PC} 1$ axis explained $25.5 \%$ of the data variation and the $\mathrm{PC} 2$ axis explained 18.0\%. The families Scarabaeidae, Curculionidae, and Carabidae were more associated with the system NF, and the attributes Bio and TOC contributed to explain this condition. The singletons, represented by "Others", were more associated with $\mathrm{EP}$, a variation partially explained by the attribute $\mathrm{Ca} /$ $\mathrm{Mg}$. On the other side of the ordination, a large portion of the families was close to the systems ICL, PA, and NT, especially Nitidulidae, Staphylinidae, Ptiliidae and Latridiidae in ICL; Chrysomelidae, Anthicidae, Salpingidae, Histeridae, and Scydmaenidae in PA; and Tenebrionidae, Silvanidae, and Leiodidae in NT. Some variables such as MWD, P, and K may help explain the participation of families present between PA and NT.

Land uses with greater supply of organic matter in the soil, especially by plant residues with different $\mathrm{C} / \mathrm{N}$ ratios and variations in decomposition rate, due to the different contents of lignin, can influence TOC contents, which may be related to the soil quality in these sites (Ramos et al., 2013). These residues come from the more diversified vegetation of NF and not only help to increase TOC contents, but also serve as food, shelter, protection, and provide more 
adequate microclimate, besides other important aspects for the development of many groups of coleopterans belonging to the families Scarabaeidae, Carabidae, and Curculionidae, observed in Figure 3a (Favero et al., 2011; Garlet et al., 2015). Some of these representatives families may also be related, to a certain extent, to the increase of Bio in NF, due to their digging activity and movement in the soil profile, along with other groups of the edaphic fauna, which contribute to the variation in the soil structure and biotic interactions in the porous space (Bardgett \& Van Der Putten, 2014).

In relation to soil chemical properties, $\mathrm{P}$ and $\mathrm{K}$, according to the study of Baretta et al. (2014) also conducted in western Santa Catarina, are among the best indicators to separate land uses, in addition to demonstrating association with NT, as in our study (Figure 3). The highest values of these attributes are associated with better soil fertility in agricultural areas, and some Coleoptera families may be benefited, especially those which include edaphic individuals, i.e., more adapted to live in the soil (Pompeo et al., 2017). Interactions between soil biology and chemistry are very complex and some studies have already demonstrated the relationship of Coleoptera groups with these variables (Farias \& Hernández, 2017; Portilho et al., 2011).

For PA and ICL, there was a high number of families associated, possibly because of crop rotation and maintenance of residues in ICL, maintenance of native vegetation, and introduction of grasses in PA, resulting in higher plant diversity. In addition, the presence of animals in these areas, with the deposition of feces, may influence the presence of some Coleoptera groups, such as those of the Histeridae family (Lopes et al., 2006). These factors can attract coleopterans with different feeding habits, phytophagous like Chrysomelidae, predators like Histeridae and Staphylinidae, saprophagous like Elateridae, and fungivores like Ptiliidae (Figure 3a). Most of the times, there are various feeding habits of species within the same family.

In the summer, for the PCA of families sampled by traps (Figure $3 \mathrm{~b}$ ), PC1 explained $28.1 \%$ of the data variation and PC2 explained 18.2\%. The families Anthicidae and Silvanidae were more related to NT and PA, and the variables that most contributed to explain this condition were RP and P. The ICL system, as well as the families Throscidae, Tenebrionidae, and Latridiidae were located in the upper left part of the ordination. Native forest was the land use related to the highest number of families, such as Curculionidae, Scarabaeidae, Staphylinidae, and Nitidulidae. Additionally, the distribution of these families showed higher association with the attributes $\mathrm{H}+\mathrm{Al}$, Bio, and $\mathrm{Ca} / \mathrm{Mg}$, which may explain this variation. Eucalyptus plantation, compared to the other LUS, was closer to the center of the ordination, demonstrating lower influence on the arrangement of the abundances of Coleoptera families. The families associated with this system were Elateridae, Dryopidae, Carabidae, and Scydmaenidae, along with the variable $\mathrm{C} / \mathrm{N}$.
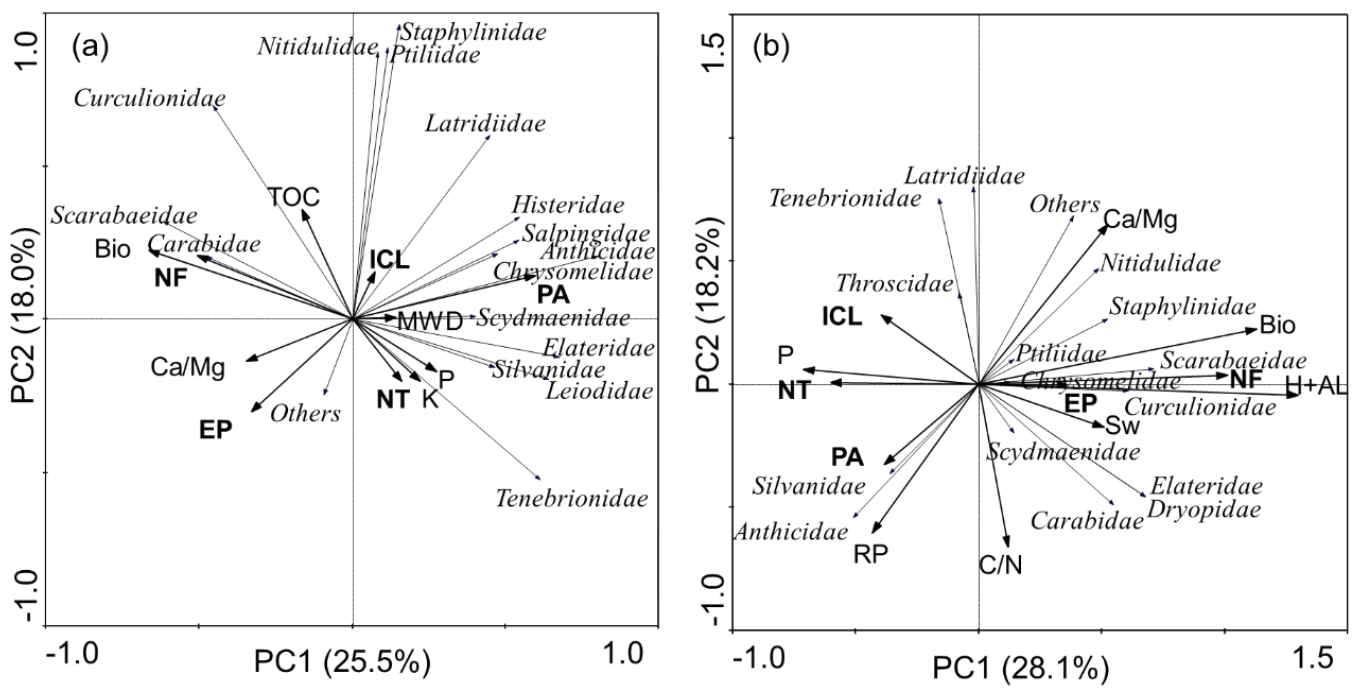

Figure 3. Principal Component Analysis for Coleoptera families (italic letters) sampled by traps, distinguishing land use systems (bold) and environmental variables, used as explanatory variables, in the winter (a) and summer (b), in the western Santa Catarina State, Brazil. NF: native forest; EP: Eucalyptus plantation; PA: perennial pasture; ICL: integrated crop-livestock; NT: no-tillage; P: phosphorus; K: potassium; $\mathrm{Ca} / \mathrm{Mg}$ : calcium/magnesium ratio; $\mathrm{C} / \mathrm{N}$ : carbon/nitrogen ratio; TOC: total organic carbon; $\mathrm{H}+\mathrm{Al}$ : potential acidity; Sw: soil water content; Bio: Biopores; MWD: mean weight-diameter of aggregates; RP: resistance to penetration; Others: rare families with only one individual. 
Such distribution of most of the families in NF, presented in Figure 3b, was also observed by Pompeo et al. (2016) in this same analysis in the summer, in the Santa Catarina highland, and some families had similar behavior in both regions, such as Scarabaeidae and Staphylinidae. The abundance of families in NF (Figure 3b) shows a clear relationship with the quantity of biopores because this attribute (Bio) is an indication of high biological activity of soil mesofauna and macrofauna (Rosa et al., 2015). In addition, these pores may serve as shelter and space for locomotion of the individuals. In this analysis, Silvanidae stands out for the proximity with NT, PA and the explanatory variable $\mathrm{P}$, and the same result was found in the study by Pompeo et al. (2016), also for the NT system. Despite that, this family was not very abundant, with only three individuals in this LUS.

In the PCA of families sampled by soil monoliths in the winter, PC1 explained $23.2 \%$ of the data variation and PC2 explained $21.0 \%$ (Figure $4 \mathrm{a}$ ). This figure shows that most groups were divided between the forest systems and ICL, and NT and PA were more distant. The families Latridiidae and Scarabaeidae were associated with NF and to lower degree with EP, and the explanatory variables were Bio, $\mathrm{Sw}$, TOC, and $\mathrm{H}+\mathrm{Al}$. In ICL, Tenebrionidae, Elateridae stood out; the space between ICL and EP contained the families Carabidae and Staphylinidae, and the attribute $\mathrm{C} / \mathrm{N}$ was the most associated with such variation. Perennial pasture was more related to Chrysomelidae and Silvanidae, and NT was more associated with 'others', possibly due to the values of $P$.
The variable 'sand' was close to the forest systems, although with lower influence.

The variables $\mathrm{Sw}$, as well as Bio, TOC, and $\mathrm{H}+\mathrm{Al}$ contributed to the presence of some groups in NF (Figure 4a), and soil water content was a determinant factor for the establishment of most soil invertebrates because, besides being an essential component for the metabolism, water also helps in the mobility of the organisms, among other processes such as reproduction (Baretta et al., 2014; Oliveira Filho et al., 2016). For instance, the Scarabaeidae family is sensitive to environmental changes, and forest areas in general have lower land use intensity and a canopy that protects the environment from direct radiation, with greater accumulation of plant and animal residues, which favors the maintenance of temperature, moisture and food supply (Garlet et al., 2015).

In the summer, $\mathrm{PC} 1$ explained $27.1 \%$ and $\mathrm{PC} 2$ was related to $17.7 \%$ of the data variation (Figure $4 \mathrm{~b}$ ). The families Carabidae, Silvanidae, Anthicidae, Phalacridae, and Salpingidae were more associated with NT and ICL, and the attributes P, pH SMP, and $\mathrm{Mg}$ contributed to explain such distribution. The families Scydmaenidae, Corylophidae, Curculionidae, and Staphylinidae, as well as the families Scarabaeidae, Elateridae, Tenebrionidae, and Chrysomelidae were more related to PA and NF, although the NF system was close to the center of the ordination and the variables TOC, Sw, TP, RP, and MR possibly explain the distribution of these groups in both systems. Eucalyptus plantation was isolated in the lower left portion of the ordination.
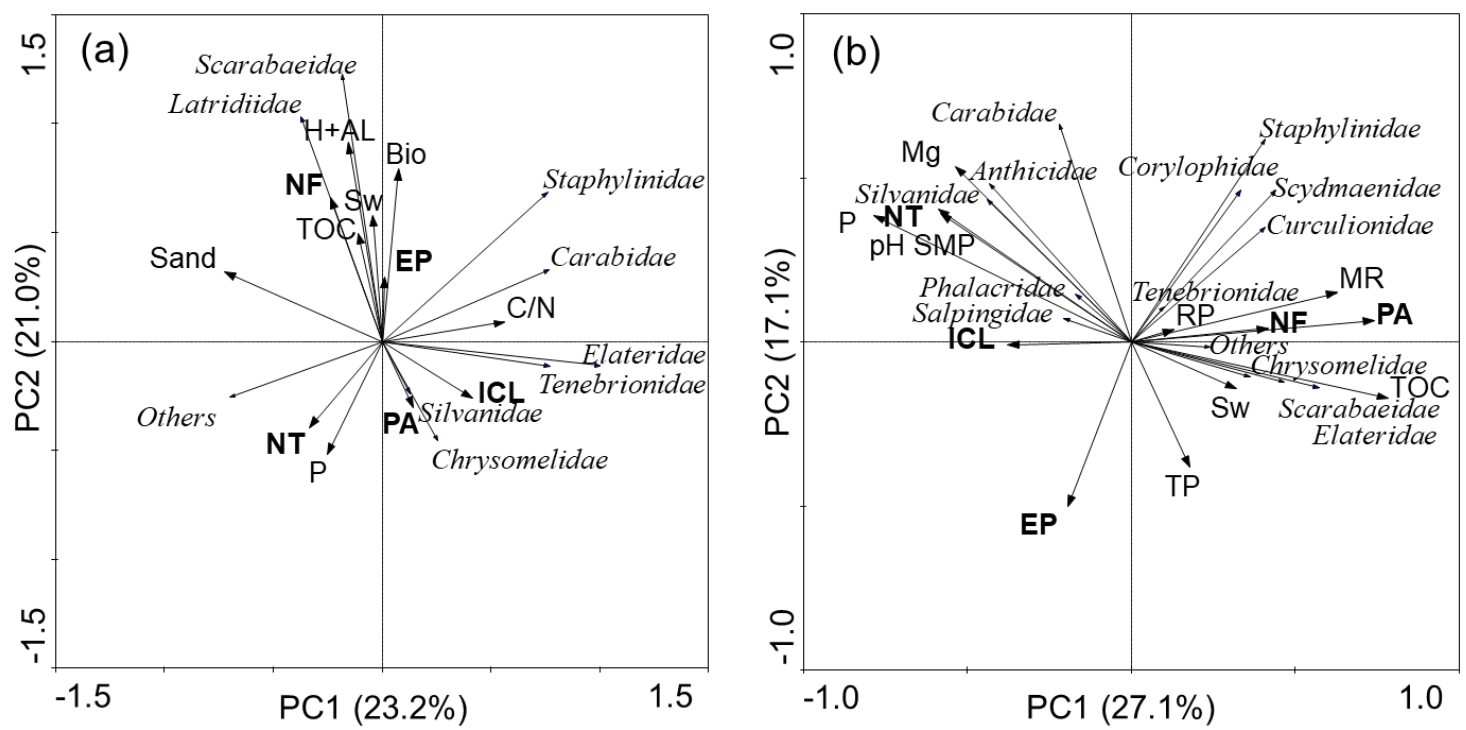

Figure 4. Principal Component Analysis of Coleoptera families (italic letters) sampled by soil monoliths, distinguishing land use systems (bold) and environmental variables, used as explanatory variables, in the winter (a) and summer (b), in the western Santa Catarina State, Brazil. NF: native forest; EP: Eucalyptus plantation; PA: perennial pasture; ICL: integrated crop-livestock ; NT: no-tillage; P: phosphorus; Mg: magnesium; C/N: carbon/nitrogen ratio; Sand: sand fraction; $\mathrm{H}+\mathrm{Al}$ : potential acidity; $\mathrm{pH}$ SMP: hydrogen potential in SMP solution; MR: microbial respiration; Sw: soil water content; Bio: biopores; TP: total porosity; RP: resistance to penetration; Others: rare families with only one individual. 
As observed for the traps in the summer (Figure $3 \mathrm{~b}$ ), the families Silvanidae and Anthicidae were related to NT (Figure $4 \mathrm{~b}$ ), which may be due to the fertilization and liming carried out in these LUS because the values of $\mathrm{P}, \mathrm{Mg}$, and $\mathrm{pH}$ SMP were higher and this condition can be observed both in the PCA and in Table 2.

Soil biota benefits from the vegetation cover which, depending on its composition and quantity, promotes greater accumulation of organic matter, providing nutrients for the development of the microbial community and increase of its biomass and activity in the soil, this last-cited represented by $\mathrm{MR}$, releasing $\mathrm{C}-\mathrm{CO}_{2}$ (Figure $4 \mathrm{~b}$ ) (Maluche-Baretta et al., 2007). Thus, areas under native vegetation, such as PA and NF, have higher incorporation of residues, favoring the increase of both TOC and MR and some groups of coleopterans.

The results shown in the PCAs corroborate the hypothesis that the environmental variables, such as type of vegetation and soil attributes, can explain the composition of the community and diversity of Coleoptera families in different environments. Thus, in both Figure 3 and Figure 4, the highest numbers of groups were related to the LUS which had native vegetation and generally greater availability of resources (NF and PA). The land use ICL was more favorable to the distribution of coleopterans in the winter, possibly because it provides better conditions for survival, through the supply of food, shelter, or other factor not discussed.

Thus, the adoption of conservationist agricultural systems, which maintain soil cover and the quality of litter or crop residues, can reduce the impacts on the communities of soil coleopterans, caused by the fragmentation of habitats and changes in land use in rural areas. Coleoptera families have various habits and functions in the ecosystems, and maintaining higher diversity of these communities can guarantee their environmental services and improve soil quality in the studied systems.

\section{CONCLUSIONS}

The distribution of Coleoptera families was influenced by the sampling season (winter and summer) and the soil variables. Biopores, water content, total organic carbon, and phosphorus contents explained the variation in the abundance of families in the systems native forest (NF), Eucalyptus plantation (EP), perennial pasture (PA), integrated croplivestock (ICL), and no-tillage (NT), in the western Santa Catarina State, Brazil.

The NT system showed higher diversity, whereas the highest abundance of Coleoptera families was found in NF. Among the families, Scarabaeidae was more associated with
NF and Tenebrionidae with ICL and PA, besides being two of the most representative groups in the study. Another family which stood out, regardless of land use, was Staphylinidae, due to the high number of individuals collected.

\section{ACKNOWLEDGEMENTS}

The authors thank the Fundação de Amparo à Pesquisa e Inovação do Estado de Santa Catarina (FAPESC) (process number 2019TR617/ FAPESC) and the Conselho Nacional de Desenvolvimento Científico e Tecnológico (CNPq) (process number 563251/2010-7/CNPq). Baretta thanks the CNPq for his research productivity grant (process number 305939/2018-1). Oliveira Filho thanks the CNPq Scholarship - Brazil (process number 155778/2018-8).

\section{SUBMISSION STATUS}

Received: 15 Feb. 2018

Accepted: 13 Dec. 2018

Associate editor: João Vicente de Figueiredo Latorraca

(1) 0000-0002-5969-5199

\section{CORRESPONDENCE TO}

\section{Pâmela Niederauer Pompeo}

Universidade do Estado de Santa Catarina (UDESC Lages), Av. Luiz de Camões, 2.090, CEP 88520-000, Lages, SC, Brasil

e-mail: pamniederauer@gmail.com

\section{FINANCIAL SUPPORT}

Conselho Nacional de Desenvolvimento Científico e Tecnológico (CNPq) (Grant/Award Number: 305939/2018-1, 563251/2010-7, 155778/2018-8) and Fundação de Amparo à Pesquisa e Inovação do Estado de Santa Catarina (FAPESC) (Grant/Award Number: 2019TR617).

\section{REFERENCES}

Alef K, Nannipieri P. Methods in applied soil microbiology and biochemistry. London: Academic Press; 1995.

Alvares CA, Stape JL, Sentelhas PC, Gonçalves JLM, Sparovek G. Köppen's climate classification map for Brazil. Meteorologische Zeitschrift 2013; 22(6): 711-728. 10.1127/0941-2948/2013/0507

Anderson JM, Ingram JSI. Tropical soil biology and fertility: a handbook of methods. 2nd ed. Wallingford: CAB International; 1993.

Bardgett RD, Van Der Putten WH. Belowground biodiversity and ecosystem functioning. Nature 2014; 515: 505-511. 10.1038/ nature 13855

Baretta D, Bartz MLC, Fachini I, Anselmi R, Zortéa T, Baretta CRDM. Soil fauna and its relation with environmental variables in soil management systems. Revista Ciência Agronômica 2014; 45(5): 871-879. 10.1590/S1806-66902014000500002

Bartz MLC, Brown GG, Orso R, Mafra AL, Baretta D. The influence of land use systems on soil and surface litter fauna in the western region of Santa Catarina. Revista Ciência Agronômica 2014; 45(5): 880-887. 10.1590/S1806-66902014000500003 
Casari AS, Ide S. Coleoptera. In: Rafael JA, Melo GAR, Carvalho CJB, Casari AS, Constantino R, editors. Insetos do Brasil: diversidade e taxonomia. Ribeirão Preto: Holos; 2012. p. 453-536.

Empresa Brasileira de Pesquisa Agropecuária - EMBRAPA. Manual de métodos de análises de solo. 2nd ed. Rio de Janeiro: Embrapa; 1997.

Erwin TL. The biodiversity question: how many species of terrestrial arthropods are there? In: Lowman MD, Rinker HB, editors. Forest canopies. Burlington: Elsevier Academic; 2004. p. 259-269.

Farias PM, Arellano L, Hernández MIM, Ortiz SL. Response of the copro-necrophagous beetle (Coleoptera: Scarabaeinae) assemblage to a range of soil characteristics and livestock management in a tropical landscape. Journal of Insect Conservation 2015; 19(4): 947960. 10.1007/s10841-015-9812-3

Farias PM, Hernández MIM. Dung beetles associated with agroecosystems of southern Brazil: relationship with soil properties. Revista Brasileira de Ciência do Solo 2017; 41: 1-13. $10.1590 / 18069657$ rbcs20160248

Favero S, Souza HA, Oliveira AKM. Coleoptera (Insecta) as forest fragmentation indicators in the Rio Negro sub-region of the Pantanal, Mato Grosso do Sul, Brazil. Brazilian Journal of Biology 2011; 71(1): 291-295. 10.1590/S1519-69842011000200008

Fountain-Jones NM, Baker SC, Jordan GJ. Moving beyond the guild concept: developing a practical functional trait framework for terrestrial beetles. Ecological Entomology 2015; 40(1): 1-13. 10.1111/een. 12158

França F, Louzada J, Korasaki V, Griffiths H, Silveira JM, Barlow J. Do space-for-time assessments underestimate the impacts of logging on tropical biodiversity? An Amazonian case study using dung beetles. Journal of Applied Ecology 2016; 53(4): 1098-1105. $10.1111 / 1365-2664.12657$

Garcia LE, Moraes RM, Vianna EES. Besouros de solo (Insecta: Coleoptera) em fragmento de mata de restinga no extremo sul do Brasil. Biotemas 2016; 29(4): 59-67. 10.5007/2175-7925.2016v29n4p59

Garlet J, Costa EC, Boscardin J, Machado DN, Pedron L. Fauna de Coleoptera edáfica em eucalipto sob diferentes sistemas de controle químico da matocompetição. Floresta e Ambiente 2015; 22: 239-248. 10.1590/2179-8087.078214

Gee GW, Bauder JW. Particle-size analysis. In: Klute A, editor. Methods of soil analysis. Madison: American Society of Agronomy; 1986. p. 383-411.

Kemper WD, Chepil WS. Size distribution of aggregation. In: Black CA, editor. Methods of soil analysis. Madison: American Society of Agronomy; 1965. p. 449-510.

Lima AC. Insetos do Brasil. T. 7, Coleópteros: $2^{a}$ parte. Rio de Janeiro: Escola Nacional de Agronomia; 1952. (Série Didática; 9).

Lima AC. Insetos do Brasil. T. 8, Coleópteros: $2^{a}$ parte. Rio de Janeiro: Escola Nacional de Agronomia; 1953. (Série Didática; 10).

Lima AC. Insetos do Brasil. T. 9, Coleópteros: $3^{a}$ parte. Rio de Janeiro: Escola Nacional de Agronomia; 1955. (Série Didática; 11).

Lopes WDZ, Lopes WCZ, Costa FH, Balieiro JCC, Prado AP. Abundância e sazonalidade de histerídeos (Coleoptera) associados ao esterco de granja aviária da região nordeste do estado de São Paulo, Brasil. Revista Brasileira de Entomologia 2006; 50(4): 492497. 10.1590/S0085-56262006000400009

Maluche-Baretta CRD, Klauberg-Filho O, Amarante CVT, Ribeiro GM, Almeida D. Atributos microbianos e químicos do solo em sistemas de produção convencional e orgânico de maçãs no estado de Santa Catarina. Revista Brasileira de Ciência do Solo 2007; 31(4): 655-665. 10.1590/S0100-06832007000400006

Monné ML, Costa C. Coleoptera Linnaeus, 1758. Catálogo Taxonômico da Fauna do Brasil [Internet]. 2018 [cited 2018 Feb. 18]. Available from: https://bit.ly/2TVm16i

Oliveira Filho LCI, Klauberg Filho O, Baretta D, Tanaka CAS, Sousa JP. Collembola community structure as a tool to assess land use effects on soil quality. Revista Brasileira de Ciência do Solo 2016; 40: 1-18. 10.1590/18069657rbcs20150432

Pompeo PN, Oliveira Filho LCI, Klauberg Filho O, Mafra AL, Maluche-Baretta CRD, Baretta D. Diversidade de Coleoptera (Arthropoda: Insecta) e atributos edáficos em sistemas de uso do solo no Planalto Catarinense. Scientia Agraria 2016; 17(1): 16-28. 10.5380/rsa.v17i1.46726

Pompeo PN, Oliveira Filho LCI, Santos MAB, Mafra AL, Klauberg Filho O, Baretta D. Morphological diversity of coleoptera (arthropoda: insecta) in agriculture and forest systems. Revista Brasileira de Ciência do Solo 2017; 41: e0160433. 10.1590/18069657rbcs20160433

Portilho IIR, Crepaldi RA, Borges CD, Silva RF, Salton JC, Mercante FM. Fauna invertebrada e atributos físicos e químicos do solo em sistemas de integração lavoura-pecuária. Pesquisa Agropecuária Brasileira 2011; 46(10): 1310-1320. 10.1590/S0100204X2011001000027

Primieri S, Muniz AW, Lisboa HM. Dinâmica do carbono no solo em ecossistemas nativos e plantações florestais em Santa Catarina. Floresta e Ambiente 2017; 24: e00110314. 10.1590/2179-8087.110314

R Core Team. The R Project for Statistical Computing [Internet]. 2017 [cited 2020 Mar. 16]. Available from: https://bit.ly/39Y6dVZ

Ramos DD, Silva EF, Ensinas SC, Carnevali NHS, Potrich DC, Freitas ME et al. Stocks of carbon, total nitrogen and humic substances in soil under different cropping systems. Semina: Ciências Agrárias 2013; 34(5): 2219-2228. 10.5433/1679-0359.2013v34n5p2219

Rosa MG, Klauberg Filho O, Bartz MLC, Mafra AL, Sousa JPFA, Baretta D. Macrofauna edáfica e atributos físicos e químicos em sistemas de uso do solo no Planalto Catarinense. Revista Brasileira de Ciência do Solo 2015; 39(6): 1544-1553. 10.1590/01000683rbcs20150033

Stockan JA, Baird J, Langan SJ, Young MR, Iason GR. Effects of riparian buffer strips on ground beetles (Coleoptera, Carabidae) within an agricultural landscape. Insect Conservation and Diversity 2014; 7(2): 172-184. 10.1111/icad.12043

Tedesco MJ, Gianello C, Bissani CA, Bohnen H, Volkweiss SJ. Análise de solo, plantas e outros materiais. 2nd ed. Porto Alegre: Universidade Federal do Rio Grande do Sul; 1995.

Ter Braak CJF, Smilauer P. CANOCO reference manual and CanoDraw for Windows user's guide: software for canonical community ordination (version 4.5). Ithaca: Microcomputer Power; 2002.

Triplehorn CA, Johnson NF. Estudo dos insetos. 2nd ed. São Paulo: Cengage Learning; 2015. 